\title{
Housing Shrewdly/Unhurried Building
}

\author{
shrewd \\ 1. Having or showing a clever awareness or resourcefulness, especially in \\ practical matters.
}

2. Disposed to or marked by artful and cunning practices; tricky.

3. Archaic Sharp; penetrating: a shrewd wind. ${ }^{1}$

\section{INTRODUCTION}

Educational Design-Build (EDB) has exploded in popularity over the last twenty years especially since it was reinvigorated by Samuel Mockbee's Rural Studio at Auburn University in 1994. ${ }^{2}$ Although they may be unique to many practicing architects today (who often say "I wish I had a project I actually got to build in School"), EDB programs and projects are found at over 2/3rd's of the 154 schools of architecture in North America today. ${ }^{3}$ These projects and experiences have come to be expected by today's students who want to be involved from the initial conceptual design to installing the kitchen sink. EDB at its best, combine's civic-minded, design education with project-based real-life experiences. These projects tend to be perceived as a proverbial "win-win" for all involved - students, faculty, clients, and the community. However, there are many difficulties and thus lessons that are not usually researched, examined, and presented in full light.

Three houses designed and built by architecture students at the University of Louisiana at Lafayette exhibit shrewdness in their clever manipulation of the ubiquitous forms and materials of southern Louisiana. These design manipulations lead to the distillation of memories and familiar associations for the viewer and inhabitants. The student designers were acutely aware of what Juhani Pallasmaa describes so aptly: "...architecture withers when it departs too far from the primary experiences and images of dwelling." ${ }^{4}$ The EVENT, NEXT, and COUR houses were each built for approximately \$115 per square foot and achieve LEED and Green Building equivalencies. ${ }^{5}$ As the first homes in their respective urban core neighborhoods in the last thirty years, they were sold at comparable market rates and have been embraced by their communities as successful, sustainable and affordable models helping to revitalize their environs.

UL Lafayette's Building Institute's Neighborhood Infill Housing Program has received many accolades including awards and celebratory press. ${ }^{6}$ The three homeowners are all very content in their homes and all the students who worked on the projects have found successful architectural careers. ${ }^{7}$ However, like all programs with many moving parts, some aspects presented great difficulties. These difficulties paired with other unavoidable circumstances
W. GEOFF GJERTSON

University of Louisiana-Lafayette 
have placed the program on temporary and possibly permanent hiatus. Although the Neighborhood Infill Housing Program presents a successful model for teaching architecture students, neighborhood revitalization, and producing affordable and environmentally-sustainable housing, it may not itself be sustainable in its current form.

\section{UNIVERSITY OF LOUISIANA AT LAFAYETTE BUILDING INSTITUTE}

The UL Lafayette Building Institute is an integrated project delivery/develop-design-build program. The program brings clients, architecture students, architects, engineers and contractors together in the design and construction of homes, installations, and community architecture. The Building Institute is structured through a graduate design studio in the fall, a construction documents course in the spring, and a construction course in the summer. Students receive academic credit for each course and in addition, several team leaders receive internships allowing them to accrue IDP credit. The Building Institute is not a simulation, it is hyper-reality. The constraints are not just "real-world" but often exceed the experiences found in professional practice. As architect-builder-developers, the students become agents of change. The thirty designed and built Building Institute projects total approximately $\$ 2$ million. ${ }^{8}$ The projects range in size from puzzle/game boxes for Hurricane Katrina evacuees to the BeauSoleil Louisiana Solar Home, UL Lafayette's award-winning entry in the Department of Energy's 2009 Solar Decathlon. ${ }^{9}$ The Building Institute was founded together with Professor Emeritus Edward J. Cazayoux, FAIA in 2002. ${ }^{10}$
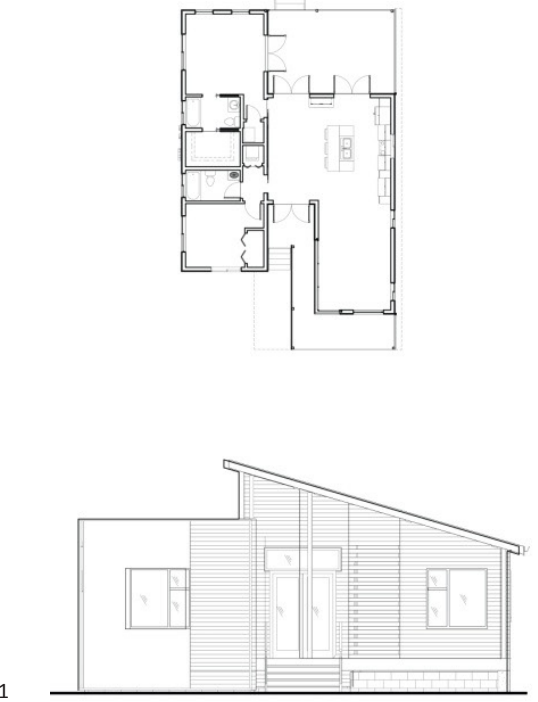
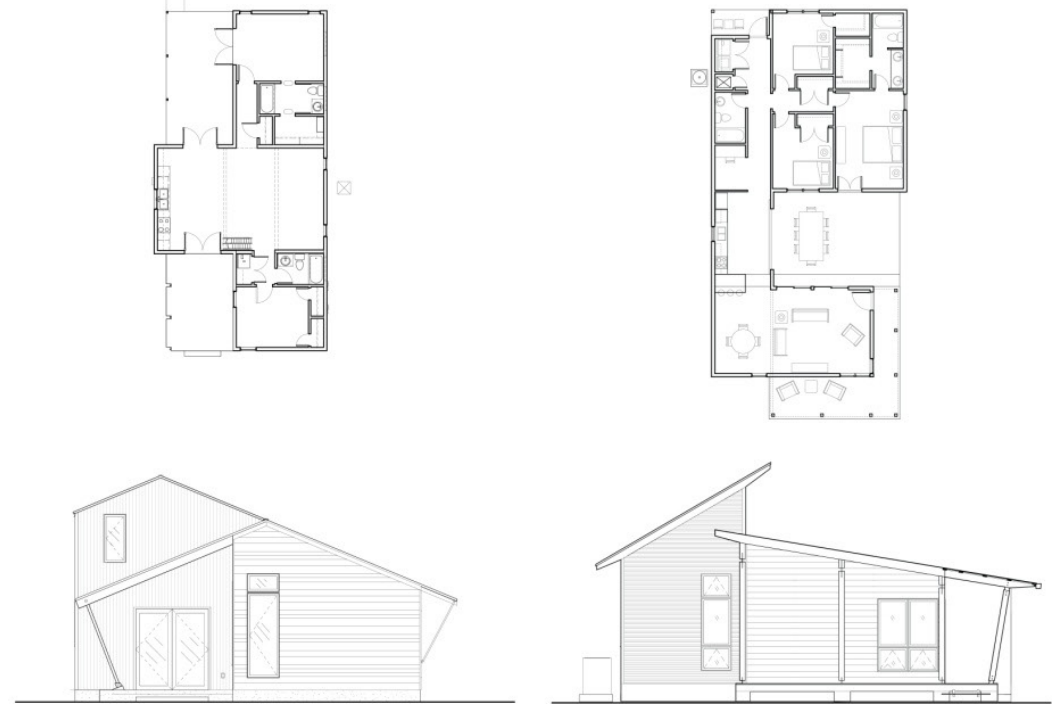

Figure 1: Building Institute's EVENT, NEXT, \& COUR Houses

\section{NEIGHBORHOOD INFILL HOUSING PROGRAM}

Following the success of UL Lafayette's 2009 Solar Decathlon house, the BeauSoleil Home, the Lafayette Public Trust Financing Authority (LPTFA) approached the Building Institute and began formulating what would become the Neighborhood Infill Housing Program. ${ }^{11}$ The Chairman of the Trust offered no-interest loans to the university for the purpose of building innovative, energy-efficient and sustainable housing prototypes in the urban core neighborhoods around downtown Lafayette, Louisiana.

UL Lafayette approved the concept and suggested that a non-profit entity, Ragin' Cajun Facilities, become the arm of the university acting as the client. Attorneys were consulted and agreements were drawn up between the LPTFA and Ragin' Cajun Facilities, between Ragin' Cajun and the Building Institute, between Ragin' Cajun and the building contractor, and between the contractor and the Building Institute. What was initially believed to be a simple arrangement became very complicated with four separate legal entities. A local 

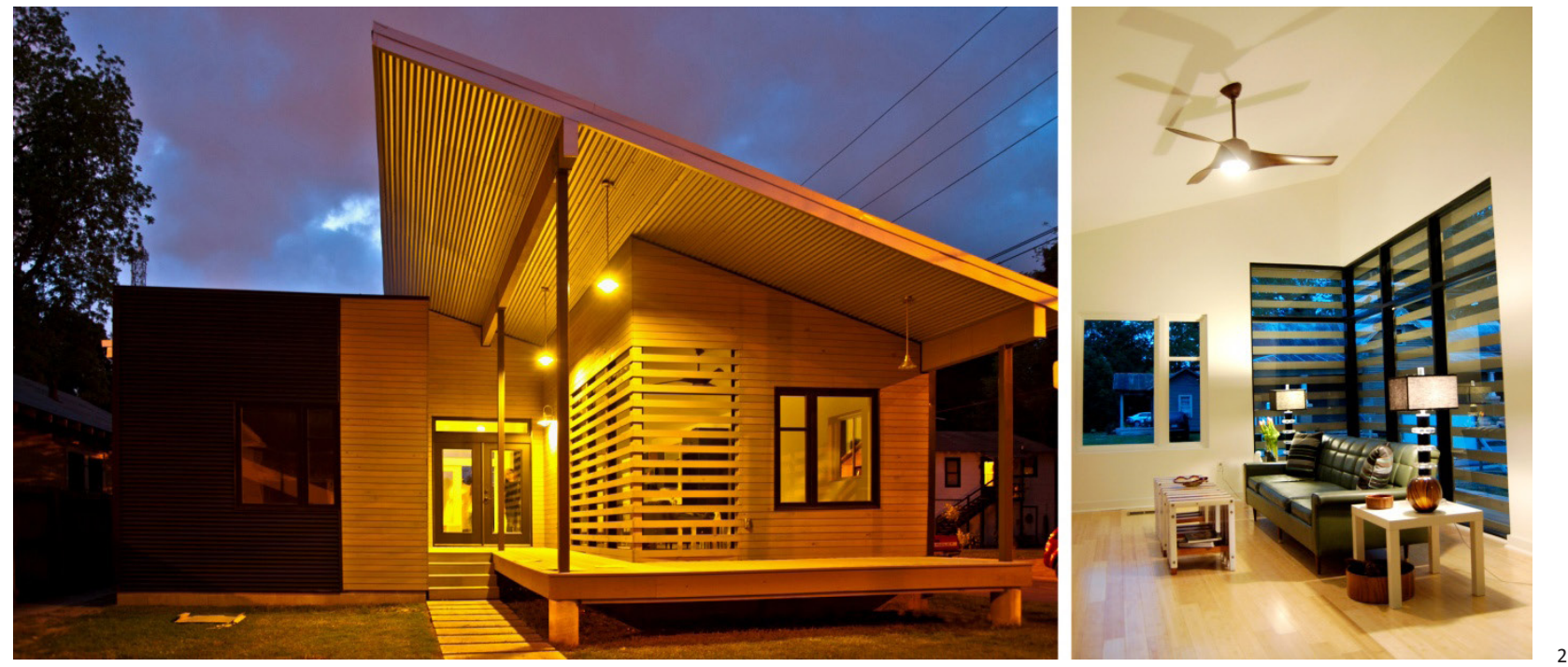

mortgage company provided pro bono services in searching for properties in the urban core neighborhoods and in helping with title services. A pro bono realtor helped sell the homes. The proceeds were then used to repay the first loan and subsequent loans were taken out to repeat the process. ${ }^{12}$

\section{EVENTHOUSE - PHOTO CREDITS ROBIN MAY}

"I believe that an early integration of students with contractors is an excellent way to open student's eyes to the realities of construction and cost estimations. Also, the process reveals the absolutely vital component to an architect's success at peaceably resolving issues with contractors." 13

\section{-Graham Goodyear, EVENThouse Student TEAM Leader}

The EVENThouse followed in the footsteps of the 2009 Solar Decathlon house, the BeauSoleil Home. The LPTFA located a piece of property that the students began the design for in the fall of 2010. However, by the end of the semester, a new lot had been found in the LaPlace neighborhood, near downtown Lafayette. This lot was actually more prominent and larger than the first lot. Four students started the process by each doing precedent analysis and then developing a design. The best of the four designs was selected by the students and in fact the best aspects of each were incorporated. The students admired the transitional "dogtrot" porch of the BeauSoleil Home and this in turn influenced the Event space which was named for its ability to accommodate any daily events from greeting guests, to hosting a party, to doing a crossword puzzle.

During the design process, the contractor, an architecture alumnus, was asked to participate in critiques. In addition the LPTFA and PAR Realty were invited to offer advice based on the projected market for the home. A target market of a single individual, a young couple, or empty nesters was identified. The home was programmed as a two bedroom, two bath residence of about 1,300 square feet. The budget was set at $\$ 120,000$ for construction not including the $\$ 10,000$ property cost. Ultimately the project went slightly over budget and was built for $\$ 155,000$.

The Design-Build aspects of the Next House had huge implications on my career by creating a holistic awareness of the residential construction process. It also instilled a confidence to make design altering decisions in a timely manner."14

-Jake Grandon, NEXThouse Student

Figure 2: EVENThouse 

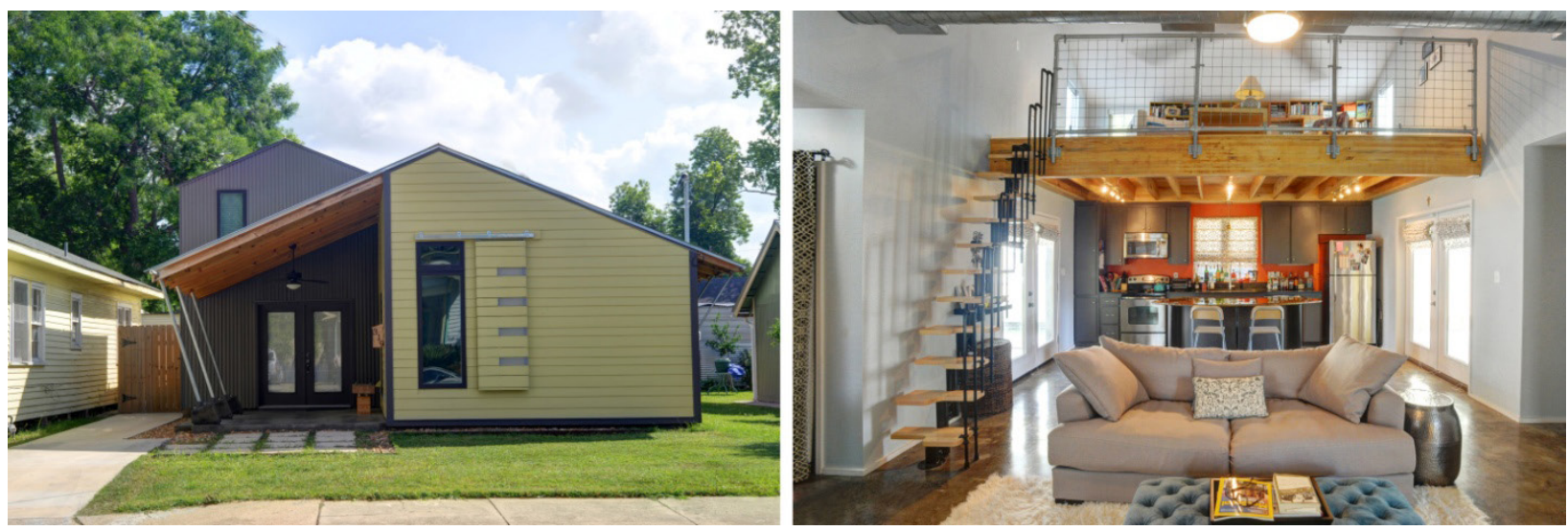

The EVENThouse revealed some of the difficulties but also gave the program confidence to continue in the fall of 2011. A lot was selected in Freetown, the up-and-coming artist neighborhood, also near downtown Lafayette. Hypothetical clients, such as the EVENThouse owner, provided input. A two story design was developed by a group of eight students. Again this lot fell through, a new lot was purchased during the spring semester, and an entirely new design was required because the lot was only thirty feet wide. As in the EVENThouse, construction documents were produced on Revit BIM software and negotiations with the contractor continued in the spring 2012 semester.

Once again the connection to the outside spaces was a conceptual driver in the design. In this case a front porch flows through the kitchen (since entertaining and cooking are so important in Louisiana culture) to the back porch. Overall the construction process was the least problematic of all three homes and when the summer semester was finished, the NEXThouse had been painted inside and out. The home was built for $\$ 145,000$.

\section{COURHOUSE - PHOTO CREDITS DENNY CULBERT \& HAYLEI SMITH}

"This project taught me that you can never give up on a project, regardless of how far along you are if you want to insure the project will be built...Since acquiring a job, I respect and am more thankful than ever for my experience. I feel much more confident in my work and decisions that are made on a daily basis, and I am trusted with more than I ever expected at this point in my career." ${ }^{15}$

— Nicholas Clesi, COURhouse Student TEAM Leader
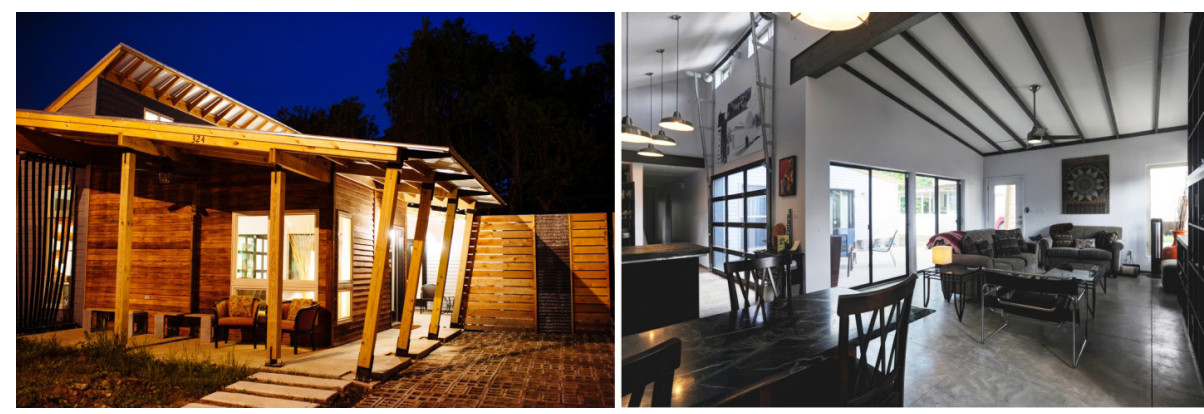

The COURhouse design process began with great optimism. Two houses had been completed, the previous home's construction process had been more seamless, and the property had been purchased in advance. Because the property was larger and a market need for a three bedroom home was recognized, the programmed square footage was raised from

Figure 3.: NEXThouse, Photo credits Haylei Smith

Figure 4: CourHouse
1350 square feet to 1,500 square feet. A team of six students analyzed the first two homes, 
the BeauSoleil Home, and other relevant precedents. The pressure was on them to raise the bar with this home. They also felt the need to invent a new typology.

The team investigated the suburban and urban typologies and determined that to attract a family to the Freetown area they would need greater privacy in this more urban setting. Therefore the courtyard typology was selected. Two contractors were consulted with from the beginning of the fall 2012 semester and eventually the two decided to collaborate on the construction. Once again the input of the LPTFA, potential homebuyers, and realtor were instrumental in assessing market needs and demands.

Construction documents and cost estimating were initiated in the spring 2013 semester and a contract was drawn up. Unfortunately, the university elevated the insurance requirements for the contractor specifying that they provide worker's compensation insurance for the students. The first contractors could not provide this so the team was left scrambling to find a new contractor. A new contractor was located but his bid came in $\$ 50,000$ over budget. The team hurried to redesign and value engineer the cost of the home down. In the process concessions were handed over to the contractor and who took full advantage of these since many were not fully documented and revised on the drawings. The home was built for $\$ 170,000$.

\section{SUCCESSES}

"The design and construction of the Nexthouse provided an opportunity for the architecture students to take part in a unique process that allows freedom in design while simultaneously exposing them to budget restrictions and market concerns... While they are more informed of the products, processes, and social benefits of conscientious collaboration, that is a comprehensive approach involving the management and coordination of many disciplines. $^{17}$

Project-based learning requires collaboration, crisis management, and risk of failure. In the safety of the classroom the threat of failure is often farthest from the mind of the students. Out on the construction site or in a city council hearing, they are fully immersed in potential crises. As Trumble and Gjertson stated in Design-Build Gone South, "For students, professional ethics and maturity constitute major challenges and responsibilities. No longer are they allowed only to address their whims in hypothetical design. Actual humans are guinea pigs in EDB. Health, safety, and welfare is not an abstraction, it is required. But also professional attire, communicative skills, collaborative respect, and compassion are in the forefront. Student responsibilities have consequences which make them infinitely more memorable and salient than traditional studio projects." ${ }^{18}$

In addition to the education of students, the EVENThouse, NEXThouse, and COURhouse were intended to help educate the public through outreach, media and the establishment of a prototype. And the construction of the homes undoubtedly helped educate the contractors in new systems and processes. The homes serve as prototypes in their respective neighborhoods for high quality design and sustainable design. Contemporary examples of architecture are often admired in the latest periodicals but until they can be experienced up close and adapted to their particular culture and climate, they do not change societal or market attitudes. In addition, the homes provide "comparables" for appraisers allowing homeowners to more readily find construction loans in the future. Homes in their neighborhoods have sold for significantly higher prices since the introduction of the EVENT, NEXT, and COUR houses. And on just a basic appearance level, the new homes have inspired renovations or at minimum the repainting of adjacent houses.

In terms of sustainable, energy-efficient design, the homes consume approximately $50 \%$ less energy than other comparable homes in Lafayette with electricity bills of around $\$ 60$ per 
month on average. ${ }^{19}$ The outwardly "green" features such as solar panels also help advertise their viability in the community. Elizabeth Brooks, the owner of the COURhouse, sums up the features of her home as only a designer and planner can: "It affords me the opportunity to engage in conversations with interested residents about distributed infrastructure, and the benefits on the environment, as well as on my pocket book, which is critical for those who are looking to learn more before they invest in incorporating these techniques and technologies into their own homes." 20

Finally, the Neighborhood Infill Housing Program encourages future public-private partnerships especially between the university and other industry and city organizations. When each organization aspires to higher goals such as public education and neighborhood revitalization, everyone benefits at an exponential level.

\section{DIFFICULTIES}

“...the more pernicious effects of an overbearing focus on a 'successful' build-at-any-cost can be that human-centered imperatives...can be overlooked." ${ }^{21}$ - Stephen Verderber

It is relatively easy to list the successes and benefits of educational Design-Build projects like the EVENT, NEXT, and COUR houses. But obviously there are difficulties because the Neighborhood Infill Housing Program is currently on hold. Part of the reason is the lack of available and affordable infill property. However, there are more significant structural and philosophical problems that will need to be addressed in order to revive the program, such as:

\section{STRUCTURAL DIFFICULTIES:}

- Legal- four separate contractual agreements with many signatories and extensive approval processes

- Insurance- the need for full insurance coverage by the contractor for high-risk students

- Short Timeframe- one-year is a relatively short time for the design and construction of an innovative home, especially in the context of the inefficiencies of an academic setting

- Faculty Overload - an average of 12-15 hours per week above and beyond typical teaching, research, and service commitments for at least 7 months of each home project ${ }^{22}$

- Student Overload-students end up volunteering well-beyond the required time for their class/grade, placing both student and faculty in a precarious position

\section{INTERNAL SUPPORT DIFFICULTIES:}

- The University does not always understand what the program is, how it works, or what its benefits are. This leads to unnecessary and redundant oversight.

- Attorneys often seem to oppose the program from the outset and put up road blocks more than helping to find solutions.

- The University does not always recognize the extensive faculty workload which the projects require by offering additional release time or assigning faculty collaborators.

\section{EXTERNAL PHILOSOPHICAL DIFFICULTIES:}

- Contractors do not understand the educational value of our projects as evidenced by their unwillingness to tolerate and subsidize the inefficiencies of building innovative structures with students.

- Contractors have a different philosophical mindset that stresses efficiencies and habit over innovation. 
- Architects, students and faculty alike need to show greater respect for the experience and craft of builders.

- Communication is hampered by these different mindsets, habits, and assumptions. Therefore expectations and responsibilities are often unclear even when contract documents exist.

- The housing market does not adequately value contemporary sustainable design as evidenced by the lack of its availability and low appraisal values.

\section{SOLUTIONS}

The solutions listed here were developed through discussions with students, fellow faculty, homeowners, and other stakeholders in the Neighborhood Infill Housing Program. One ingredient in short supply comes up again and again when assessing the long-term sustainability and viability of the program: TIME.

Students and homeowners alike recommend that the cycle for each home be extended to two full years. A two year cycle would allow the first fall semester for schematic design, the first spring semester for design development, the first summer for construction documents, and the second fall, spring, and summer for construction. Additionally, more time in studio could be devoted to property acquisition, marketing, and real estate sales. Obviously the downside of this extended cycle is that the same group of students would probably not be able to stay with the project in their curriculum through the entire two years. However, the phases they were involved in would be more thoroughly researched and experienced. A new mantra for this approach might be called "unhurried building."

With regard to faculty and student overloads, lengthening the projects may also provide relief. Or if a year break was taken between projects this would also allow time for recovery and reflection. The pitfalls may be the loss of momentum and reduction of efficiencies gleaned through fast repetition. As another relief measure, additional faculty could be added to teach the program. However, this is problematic due to tenure and promotion policies which often preference individual research agendas.

Contractor difficulties could be reduced through self-contracting by the university or another internal partner (IE Tulane's URBANbuild). ${ }^{23}$ In this way, the contractor would be a known quantity eliminating potential conflicts. Obviously having an internal contractor places greater liability on the university. Another solution would be to remove the Building Institute completely from under the wing of the university as its own not-for-profit thus streamlining the process (IE Kansas' Studio 804). ${ }^{24}$ However, these more insulated models do not allow students to participate in true integrated project delivery with multiple stakeholders.

Finally, limiting the number of new designs so that prototypes would be refined and perfected over several years, instead of reinventing new designs and typologies every year, would result in greater stability and less risk. Or designing larger, multiyear projects such as multi-family live-work developments or even tiny-home villages, would result in enhanced efficiencies and economies.

\section{CONCLUSION}

For the profession, Design-Build as a project delivery system is growing and academic programs can provide a proving ground for optimizing and expanding this system. The community service component of EDB sets an example for the profession by better educating the underserved public as to the importance of design. And through Design-Build, designers sustain the design process during construction and introduce craft at every level. Value-added

\section{ENDNOTES}

1 The Free Dictionary website, http://www.thefreedictionary.com/shrewd, s.v. "shrewd," accessed April 30, 2015

2 Andrea Oppenheimer Dean and Timothy Hursley, Rural Studio: Samuel Mockbee and an Architecture of Decency. (New York, Princeton Architectural Press, 2002.

3 Association of Collegiate School's of Architecture website, http://www.naab.org/architecture_programs/home and Author's own research/survey: Gjertson, W. Geoff. “A House Divided: Challenges for Design-Build Programs in Architecture Schools." Local Identities Global Challenges: 2011 ACSA Fall Conference, Houston. Edited by Ikhlas Sabouni, and Jorge Vanegas, ed. (2012): 23-35.

4 Juhani Pallasmaa, Architecture and Human Nature: A Call for a Sustainable Metaphor. In Bryan MacKay-Lyons, Edited by Robert McCarter's, Local Architecture. (New York, Princeton Architectural Press, 2015, p. 38.)

5 The cost of the homes was $\$ 111, \$ 113$, and $\$ 115$ / sf respectively- refer final illustration- comparison chart. None of the homes received actual LEED or Green Building certifications due to lack of funding and time to complete the process.

6 Some of these accolades include several blind peer-reviewed papers/presentations, the Independent Weekly's INDesign Awards for each of the three homes, a Freetown-Port Rico Neighborhood Community Pride Award, and numerous periodical articles praising the program in local and regional press.

7 W. Geoff Gjertson, Generating Hope: Stories of the BeauSoleil Louisiana Solar Home. (Lafayette, LA, UL Press, 2014.)

8 Building Institute website, http://ulbuildinginstitute.com/about-us/, accessed April 30, 2015.

9 A majority of all Building Institute funding comes from outside sources.

10 The Building Institute is Co-Directed by Professors W. Geoff Gjertson, AIA and Hector LaSala.

11 Lafayette Public Trust Financing Authority website, http://www.lptfa.org/about-us/, accessed April 30, 2015.

12 None of the three homes generated a profit.

13 Graham Goodyear, email to author, April 27, 2015

14 Jake Grandon, email to author, April 26, 2015

15 Nicholas Clesi, email to author, April 29, 2015

16 Jake Grandon, "Travel/Green Building: Young Architects Forum Connection," November 2012. YAF PDF, p. 63, http://www.aia.org/aiaucmp/ groups/ek_members/documents/pdf/aiab096572. pdf, accessed April 30, 2015.

17 Edutopia website, http://www.edutopia.org/ project-based-learning, accessed April 30, 2015 
18 W. Geoff Gjertson and Christopher D. Trumble, "Design-Build Gone South," Proceeding of the Fal ACSA Conference, WORKING OUT: thinking while building, 2014, p. 199

19 Catherine Landers, Elizabeth Brooks, and Kirk Warner, interview by author, Lafayette, LA, June 14, 2013.

20 Ibid.

21 Stephen Verderber, "Territories of Educational Design-Build: Toward and Evidence-based Discourse," Proceeding of the Fall ACSA Conference, WORKING OUT: thinking while building, 2014, p. 180.

22 Although the author received some additional compensation for project management it was well below minimum wage $(3,000$ hours of additional work compensated by $\$ 6,000-8,000$ per project= $\$ 2.33$ per hour).

23 Urbanbuild website, http://tulaneurbanbuild. com/index2.php\#/home/, accessed April 30, 2015.

24 Studio 804 website, http://www.studio804.com/, accessed April 30, 2015. design like custom furniture and custom details connect the architecture to the homebuyers and ultimately help "make the sale." According to Catherine Landers, the fact that the "student's hands were invested" in the project convinced her to buy the NEXThouse.

The profession can also learn from the Building Institute's shrewd design process. Penetrating research is performed. Students carefully listen to potential clients. Conclusions are shared, tested, and documented. A variety of design schemes are explored individually. Then as an integrated team, a democratic design constitution is established and a final design is developed. This non-hierarchical process results in better collaboration and team member ownership, AND ultimately better design.

EDB programs, like the Building Institute, teach architects to be proactive and initiate their own projects. As a profession we cannot wait for the public, the market, or developers to ask for better design, we have to set an example by becoming agents of change. EDB programs are necessary for the profession's own survival through better prepared future architects and therefore it is hoped that architecture firms will make greater investments of time and money in their local universities.

For the academy, the risk of losing programs like the Neighborhood Infill Program should prompt university administrations to make a larger and more thorough commitment to EDB. Faculty and students have to be more patient and content with incremental project development and willingness to accept lack of full-ownership of projects from year to year. Program accreditation should require Design-Build programs to meet additional criteria and NCARB should allow greater IDP experience hours from EDB for interns/students.

The subtitle of this paper, "unhurried building" is intended to be a rallying cry for EDB and professional practice. This "build-at-any-cost" mentality, as Verderber calls it, has to be resisted. Unhurried building is an attempt to codify the methodology of building with quality and sustainability as primary goals. Unhurried building does not mean that sustainability is not urgently needed but instead that we must conduct careful observation, planning, and construction to reach these goals. Unhurried building also reflects the mindset that the owner, architect, contractor and community must have during the process. Our agenda must be directed towards long-term goals not short-term gains. On a micro-level, unhurried building calls for a new paradigm of design research, construction documentation, supplychain control, and building craft. When we hurry these processes we lose quality BUT more importantly we lose sight of our most critical responsibility- the health, safety, and welfare of the humans, animals, plants, and environment of our planet. 


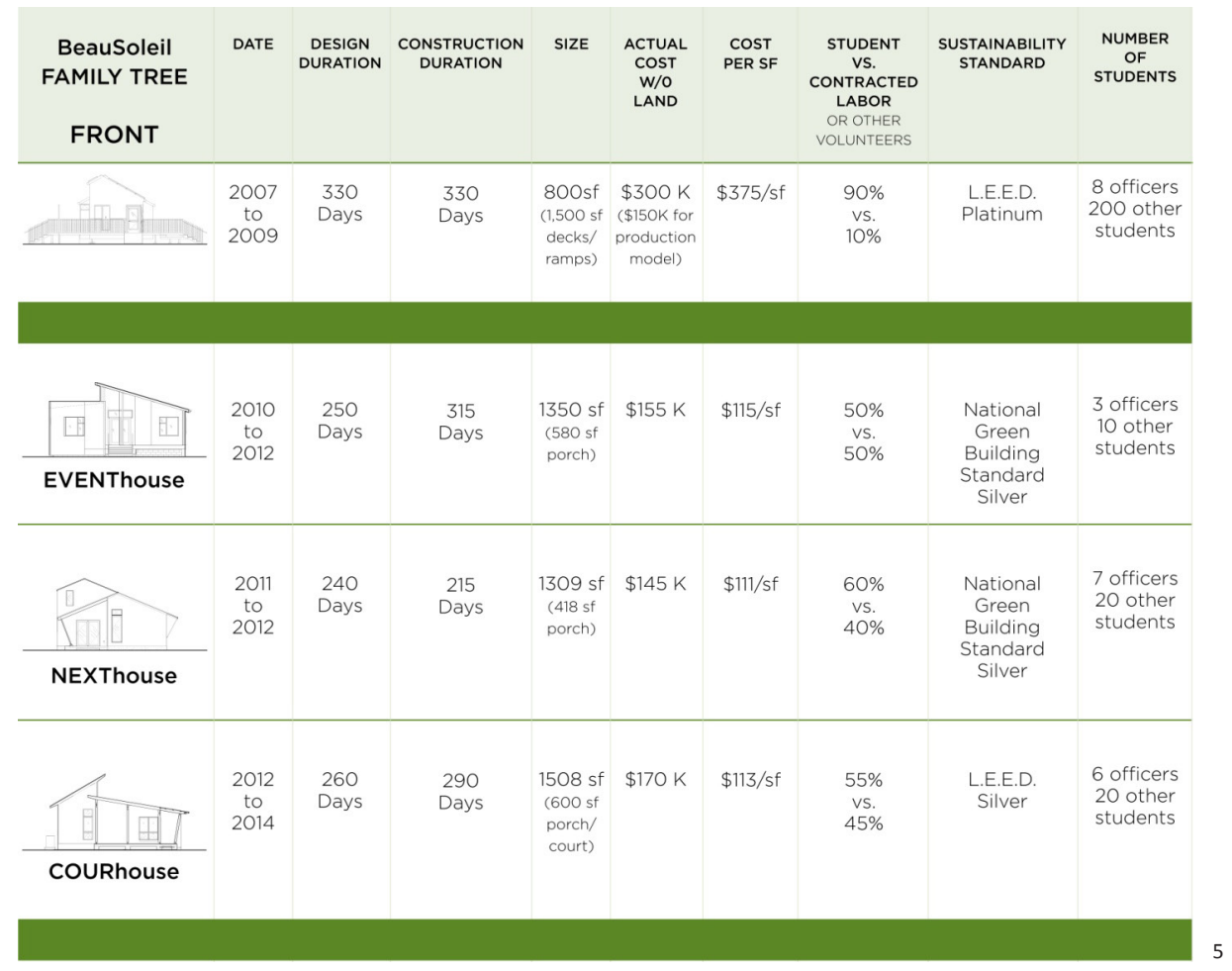

Figure 5: Comparison Chart - Graphics by Megan Barra 